\title{
Commission 41: HISTORY OF ASTRONOMY/HISTOIRE DE L'ASTRONOMIE
}

\author{
(A Joint IAU-IUHPS Commission)
}

PRESIDENT: S. M. R. Ansari

VICE-PRESIDENT: S. J. Dick

ORGANIZING COMMITTEE: S. Débarbat, A. Gurshtein. S. Nakayama \& J. D. North

\section{INTRODUCTION}

The membership of the Commission stands, with the election of 18 IAU members and 12 historians at the XXII GA (1994), at 155 presently (Sept. 1996). Note the increase in membership, which is $24 \%$ and which hopefully may go to $30-35 \%$ by XXIII GA (1997). The Commission has put a message on WWW for all IAU members/presidents of various commissions to join the Commission 41 in a big way, so that it can extend its scope of activities further. Besides holding a Joint Discussion of its own (No. 17), Commission 41 is co-supporting JDs 8, 20 and 23.

In the following we report briefly significant researches carried out in the History of Astronomy [HA] in the last two years. A select bibliography is appended at the end. Reference to the titles of research papers/monographs in this report is marked by an asterisk. Evidently the report is not comprehensive for want of time, space and material at our disposal.

\section{WORK-IN-PROGRESS}

S. Débarbat (Paris) has been working in various subjects: cartography by astronomers, metric system, astronomical instruments*, historical studies related to IAU, etc. She is also involved in organizing the exhibition at the 150th Anniversary of the Discovery of Neptune in 1846, and VIIIth Journées Systèmes de Référence Spatio-temporels at Paris Observatory. S.J. Dick (Washington) continued working on SETI, also the history of U.S. Naval Observatory. Recently, his book on The Biological Universe* has been published. J. D. North (Utrecht) worked on medieval cosmology and diverse topics, like aspects of language of medieval mathematics, and Sun and Moon in The Clerk's Tale. Besides, he has published two monographs*. Another active historian, E. Proverbio (Milano), has been involved in organizing meetings on HA under the auspices of the Italian Astron. Soc. $\mathrm{He}$ is continuing work on Italian astronomical institutions, and has just published Vol. I of the Correspondence of Giovan Stefano Conti*. Ileana Chinnici (Palermo) has published a compilation of Pietro Tacchini's correspondence. Magdalena Stavinschi (Bucharest) is working on the first IAU member from Romania, Nicolae Donici, and organized a symposium to commemorate his 120th anniversary. Maria Stathopoulou (Athens) and her colleagues are working on history and philosophy of astronomy and have published four books on Uranography, time in astronomy, calendars, etc.

In the field of Arabic-Islamic Astronomy [IA], the major publication is by G. Saliba (New York). His History of IA/Islamic Planetary Theories* summarises this important field. Further, by analysing the Arabic text of Muh. b. Müsa (9th c.) he shows that the adequacy of Ptolemaic astronomy was debated 400 years before the Marägha school. S. M. R. Ansari (Aligarh) has published an important study on the transmission of IA in medieval India*. E Ihsanoglu (Istanbul) has compiled history of Ottoman literature of astronomy as part of a bigger project: Introduction of Modern Science to the Ottoman World. M. Yano (Kyoto) has completed his study of Kushyār's Astrological Treatise, and worked out planetary ephemerides in Chinese written by an Indian priest ca. $800 \mathrm{AD}$ and preserved in a Buddhist scripture. With B. van Dalen (Holland), Yano is currently 
working on the project: Islamic Influence in Astronomical Tables from the Yuan and Ming Dynasties. The first part of this project, Planetary Latitude Theory in Huihui-li, has already been reported. These Chinese tables are clearly related to the Islamic Zīj by Abū Muh. Atā al-Sanjufinin (fl. ca. 1366). The Iranian historians have published a Persian translation of E. Kennedy's Survey of Zijliterature (by M. Bagheri) and G. Saliba's paper on The Astronomical Tradition of Maragha (by H. T. Rad). Further, Bagheri has been working on Kushyär's Zijj and on the tract Celestial Distances and Sizes, also on al-kāshîs famous letter to his father, based on a new manuscript with marginal notes. To note are the important study of T. Heydarzadeh, Assumptions on Avempace's NonPtolemaic System, and A. Birashk's book on Chronology*, in Persian.

In the field of Indian Astronomy, techniques to derive the planetary longitude corrections of Indian astronomers (11-16th c) by D. Pingree*, and mathematical methods in Sanskrit astronomical tables in general by Kim Plofkar (both of Brown Univ.) have been worked out. V. Sharma (Wisconsin) has published a monograph on Jai Singh's Astronomy*, and recently his interest shifted from astronomical instruments to ancient Indian chronology. Another very active Indian historian is S. R. Sharma (Aligarh), who is preparing a world-list of Indian astronomical and time-measuring instruments. Recently he has published an important study on the Lahore Family of Astrolabists*. S. M. R. Ansari is continuing his studies in Modern Astronomy in Indo-Persian Sources. Further, his edition of the Persian text of $Z \bar{i} j-i$ Muhammad Shahi (Jai Singh's Astronomical Tables) is almost complete for publication. Vol. 1 comprises the text with a long introduction on the problematique.

In the Astronomy of the Far East, Y. Maeyama (Frankfurt) continued to work in the evolution of Chinese Astronomy, even HA in Babylonia, Greece and late Renaissance. Recently he has published an important study on the determination of the Sun's orbit*. Other topics on which some work has been done are: Interaction of Chinese and Islamic Astronomy and historical astrology (by J. Xiaoyuan, Shanghai), Modern Astronomy in China particularly on Ferdinand Verbiest's contribution (by Xi Zezong, Beijing) and solar eclipse and meteor showers in Chinese records (by K. -Y. Chen, Florida). In South Korea I.-S. Nha is actively working on Korean Observatories, particularly of King Sejong's palace observatory and its instruments, Korean star maps, Jesuits' contribution to Korean astronomy, etc. He was one of the main spirits behind the two international conferences on Oriental Astronomy held in Seoul (Korea) and Yingtan (China). He is also involved in the reconstruction of King Sejong's instruments. Bambang Hidayat (Sandung) has been working on the foundation of Bosscha Observatory, in which three Dutch schools of astronomy (Leiden, Groningen and Utrecht) were actually involved.

\section{NEWSLETTERS/BULLETINS}

A Newsletter of the Historical Section of the British Astronomical Association is being published by the Director, A. J. Kinder (London). Besides news items on HA it contains a list of papers published on history and biographical aspects of astronomy. Kinder is also planning to found a Society for the History of Astronomy. W.R. Dick (Potsdam) is publishing very regularly Mitteilungen zur Astronomie-Geschichte with the collaboration of the working group for HA of the German Astronomical Society. This newsletter contains world-wide items on $\mathrm{HA}$ and is quite comprehensive. The History of Astronomy Division of the American Astronomical Society also publishes a quarterly Newsletter, with extensive bibliography. 


\section{SELECTED BIBLIOGRAPHY}

Ansari, S.M.R.: On the Transmission of Arabic-Islamic Astronomy to Medieval India, Archives Int. d'Histoire des Sci. 45, No. 135 (1995), 273-297.

Birashk, A.: Three Thousand Years of Comparative Chronology, Tehran, 1994.

Chabas, J. and Goldstein, B. R.: Andalusian Astronomy: al-Zij al-Muqtabis of Ibn al-Kammad, Archive Hist. Exact Sci. 48 (1994), 1-41.

Débarbat, S.: An Unusual Use of an Astronomical Instrument: The Dreyfus Affair and the Paris "Macro-micrometre", J. Hist. Astron. 27 (1996), 45-52.

Dick, S.J. : The Biological Universe: The Twentieth Century Extraterrestrial Life Debrate and the Limits of Science, Cambridge Univ., 1996.

Dobrzycki, J. and Kremer, R.L.: Peurbach and Marāgha Astronomy. The Ephemerides of Joh. Angelus and Their Implications, J. Hist. Astron. 27, no. 3 (1996), 187-237.

Goldstein, B.R.: Astronomy and Astrology in the Works of Abraham ibn Ezra, Arabic Sci. and Phil. 6, No. 1 (1996), 9-22.

von Gotstedter, A. (Ed.): Ad Radices. Festband zum funfzigjahrigen Bestehen des Instituts fur Geschichte d. Naturwissenschaften d. Univ. Frankfurt, Franz Steiner Vorlag, Wiesbaden, 1995.

Ihsanoglu, E. (Ed.): Fatihten Günümüzo Astronomi, Istanbul, 1994.

Maeyama, Y." Determination of the Sun's Orbit by Hipparchus, Ptolemy, al-Battāni, Copernicus and Tycho Brahe, Archive Hist. Exact Sci. 50 (1996).

Nha, I.-S and Stephenson, F.R. (Ed.): Proceedings of the First International Conference on Oriental Astronomy, from Guo Shoujing to King Sejong, Kyongshin-sa, Seoul, 1996.

North, J.D.: The Fontana History of Astronomy and Cosmology, London, 1995.

North, J.D.: Stonehenge: Neolithic Man and the Cosmos, London, 1996.

Pingree, D.: Bija Correction in Indian Astronomy, J. Hist. Astron. 27 (1996), 161-172.

Proverbio, E.: Correspondence of Giovan Sefano Conti with R. G. Boscovich, covering 1760-1771, vol. 1 Milano, 1996.

Said, S.S. and Stephenson, F.R.: Solar and Lunar Eclipse Measurements by Medieval Muslim Astronomers, I. Background, J. Hist. Astron. 27 (1996), 259-273.

Saliba, G.: A History of Arabic Astronomy: Planetary Theories during the Golden Age of Islam, New York, 1994.

Sarma, S.R.: The Lahore Family of Astrolabists and their Ouvrage, Studies in History of Medicine and Science, 13, No. 2 (1994), 205-224.

Sharma, V.N. Swai Jai Singh and his Astronomy, Delhi, 1995.

Stehenson, F.R., Zhentao, X. and Yaotioa, J.: Astronomy on Oracle Bone Inscriptions, Q. J. Roy. Astr. Soc., 36 (1995) 397-406

Assistance provided in the compilation of this Report by all scholars of history of astronomy and particularly by Dr. S J. Dick (Washington) is gratefully acknowledged.

S. M. Razaullah Ansari

President, Commission 41. 